\title{
Biographical trajectories and parenting projects of same-sex couples
}

\author{
Filomena Santos \\ University Institute of Lisbon (ISCTE-IUL) / Centre for \\ Research and Studies in Sociology (CIES-IUL) and \\ University of Beira Interior-Sociology Department, Portugal \\ namesantos@sapo.pt
}

\author{
Rita Dias \\ C3I - Polytechnic Institute of Portalegre and University of \\ Beira Interior, Portugal \\ dias_93@hotmail.com
}

\begin{abstract}
Based on qualitative interviews with Portuguese nonheterosexuals young men and woman living in conjugality, the article aims to analyses their biographical trajectories and parenting projects.

The findings reveal that the main obstacles to the conception and implementation of the parenting projects for same-sex couples are the internalized homophobia; the «drama» that is still the revelation of the non-heteronormative sexuality to close relatives; ideal norms and representations about male and female social roles, mainly the motherhood ideology. Despite the recent legal changes about the same-sex marriage and same-sex adoption in Portugal, others structural constraints such as the work precariousness of the Portuguese young adults have also a negative and a cumulative effect on the transition to parenthood for nonheterosexuals men and woman.
\end{abstract}

Keywords- Gender; Same-sex couples; Parenting projects; Homoparenthood; Individual trajectories and biographies; Family dynamics

\section{INTRODUCTION}

Despite the legal recent changes that allows same-sex marriage since 2010 and same-sex couples' adoption since 2016 in Portugal, homoparenthood is still an issue that challenges the heteronormativity and therefore it is an issue that has not social consensus [1].

The normative heterosexual and bi-parental family is questioned by the homoparenthood because parental models are rooted in conventional gender roles, which means that people believe that there are specific male and female qualities that cannot be separated from assigned sex and the correspondent gender role.

Several studies $[2 ; 3 ; 4 ; 5 ; 6]$ had shown that homoparental families do not differ much from heterosexual families on parental competences, and that these competences do not depend on sexual orientation or gender identity.
However, the importance of the biology remains on the social imaginary and there is a privileged status of the biological family ties over the affective ties, as well as a privileged status of the ideal norm of heterosexual, monogamous and reproductive couple over different ways of being a family.

In Portugal there are several studies and ongoing research projects about gender citizenship and sexual rights ${ }^{1}$ [7], the micro politics of parenting in a comparative perspective (Portugal, Italy, and Spain) ${ }^{2}$ [8; 9], the history of LGBT movements in Portugal [10], the discrimination of nonheterosexual people [11], and about the attitudes of Portuguese people towards the homoparental competences and the child development $[12 ; 1]$. Despite the research about the division of house chores in same-sex couples [13], there is still little research that study on the «inside» of the non-heterosexual conjugality and parenthood and from the non-heterosexual's people perspective.

The low fertility in Portugal and the lack of studies on the homoparental family dynamics in the Portuguese context come together to justify our research interest in giving voice and space to the future non-heterosexual parents to speak and show their point of view.

We were interested in knowing their biographical trajectories, mainly about the "self-disclosure» of the sexual orientation, and their expectations, representations, ideal norms and projects regarding maternity and paternity in their multiple ways of access (adoption, help from a friend, artificial insemination, assisted reproductive technology, surrogacy...).

Can same-sex couples resist the heteronormative gender order $^{3}$ and challenge the conventional binary classifications of femininity and masculinity? Is there a gender difference on signification about being father and being mother? Which are the preferences about the ways of access to homoparenthood? Are the stereotypes about the male/paternal and the

coherent, natural and privileged. It involves the assumption that everyone is heterosexual, and that heterosexuality is the ideal and superior to homosexuality or bisexuality. Heteronormativity also includes the privileging of normative expressions of gender - what is required or imposed on individuals in order for them to be perceived or accepted as a «real men» or a "real woman» as the only available categories" (Oliveira, 2010 in [16] Dias, 2018: 22). 
female/maternal social roles more easily deconstructed on the same-sex couples?

We have been working on this issues in priors works [14; 15], and therefore we wanted to answer the research questions mentioned on the previous paragraph. On the context of a master thesis in sociology [16], we worked with empirical data collected from four biographical interviews in depth from nonheterosexual young adults living in conjugality, with no children and from different social backgrounds.

\section{THEORITICAL AND METHODOLOGICAL APPROACHES}

The biographical approach used in this study focuses on the social action flow, mainly in the contexts where those actions take place. We started from the assumption that both agency ${ }^{4}$ and structure shape the construction of individual biography.

The research is based on biographical interviews in which individuals are perceived as active subjects and endowed with agency. However, particular attention is paid to categories of belonging such as gender and social class. We believe that those structures of belonging play an important rule in the way interviewees design their parental projects.

According to the interactionist perspectives in sociology, the roles and norms of gender and the personal autonomy are negotiated by social actors in the flow of their biographical trajectories.

Several studies carried out in Portugal [17, 18, 19], have highlighted as shaping variables of family behaviors and representations both gender and social class.

To fulfil the research's purpose, we interviewed three females and one male with different school and professional backgrounds, all of them in an ongoing homoaffective conjugality and with a parenting project in mind. At Figure 1 we describe some background variables and some important information about the individuals' biographies of our interviewees (Luís, Sónia, Ema and Andreia).

The cases were founded by the "snowball effect", among the network of the researchers and the interviewees themselves ${ }^{5}$. The use of a snowball sample had the advantage of obtaining ordinary people, as opposed to individual militants in organizations that fight for LGBT rights, usually more predisposed to be interviewed for publicly assuming their sexual orientation and gender identity. On the other hand, our sample (see figure 1) includes non-heterosexual people residing in medium-sized cities (Guarda and Castelo Branco), which are usually less studied. In addition, all of our interviewees, even those residing in the Lisbon region, lived their childhood and adolescence in small villages and towns and their families of origin remain in rural areas.

In the scope of Bertaux's perspective [20] there was a need of multiple biographies analyses to carry out sociological knowledge. In recent sociological theory, however, there are other sociologists in the scope of the narrative- interpretative school, advocating the possibility to "treat each biography as a unique case that contains sociological relevant information" [21]. As Cardenal says "is not, therefore, the accumulation of cases which will enable sociological knowledge, but the ability to make the connections that go from biographical experience to structural constrains" because "the social is inscribed in the individual" and vice-versa [21].

Biographical interviews were conducted in order to explore not only everyday life, future projects and relevant past events, but also, to explore the social actor's perspective. The technique of the semi-directional interview served as the basis for the collection of this type of information.

With those methodological and theoretical frameworks in mind the cases were analyzed, in a first moment, case by case, as a unique and interesting history. In a second moment, we analyzed the cases by comparing each case with one another. In this way, we underline certain patterns, tendencies and regularities that can be discussed in a comparative perspective with results from other relevant studies.

Luís is a 30 years old IT technician and a master's student. Rafael is a 23 years old graduate student and does not have a paid job. They live together for two years now (City of Guarda).

Sónia is a 25 years old optometrist. Patrícia is 27 and is an IT consultant. Both of them hold a licentiate degree. They live together for two years now (City of Lisbon).

Ema is a 27 years old secretary in a real estate agency and holds a master degree. Inês is 24 , has the 9th year of schooling and works as a cleaner. They live together for nine months now after 4 years of dating (City of Guarda).

Andreia is a 26 years old call assistant and has the 9th year of schooling. Filipa is 27 and has the 12th year of schooling. She works in the same place as Andreia and is a call assistant too. They live together for two years now in the same house of Andreia's mother (City of Castelo Branco).

Figure 1. Description of the Interviewees and their Partners

\section{RESULTS AND DISCUSSION}

In the context of the theoretical framework that oriented the interviews analysis, we considered important to wonder what have changed and what have remained about this subject.

Whereas the relatively young age of the interviewees, our study confirms the great generational changes that have occurred in Portugal in the last decades. These transformations reflect on social values, representations and practices and are relatively transversal to rural and urban environments and to different class contexts $[17 ; 18 ; 22]$. These changes are reflected in the family modernization trends in the scope of the great historical

\footnotetext{
${ }^{4}$ Understood as the autonomy of individuals to act in a reflexive way that leads to reproduction or to social change. It can lead too a combined effect of social change with social reproduction of practices, norms and representations, mainly those about the heteronormative gender role (Cf. Giddens, A. 2000, The Duality of Structure, Oeiras, Celta Editora).
}

\footnotetext{
${ }^{5}$ None of the interviewees has a relation of friendship or family with the researchers. Two of the interviewees (Luis and Ema) were nominated by masters students. One of the interviewees, in turn indicated Andreia. Sónia was recruited using the network of acquaintances of a relative of one of the researchers.
} 
movements of privatization, sentimentalization, individualization and de-institutionalization marked by family sociologists ${ }^{6}$.

The analysis of the interviewees' discourse reveals a normative decline of the institutional family model and an increase on the democratic family dynamics, based on the ideal of conjugal equality and on companionship values. The formation of the couple and the family becomes less and less linear and more diversified, according to the biographical path and individuals' choices. The couple's relationship is constructed step by step and there is a clear and a strong separation between sexuality and marriage and between conjugality and marriage [17]. Indeed, all the interviewees started a conjugal cohabitation without marriage and only Andreia has the dream to marry. The other interviewees have nothing against marriage, but they do not consider it as an important matter.

This is a curious fact, considering that until 2010, same-sex civil marriage was not legally allowed in Portugal and that this was considered one of the most important achievements for LGBTQI rights [23]. Nevertheless, there seems to be an approximation between heterosexual couples and same-sex couples, also in this subject, regarding the movement of deinstitutionalization and informality of conjugal and family life. The only interviewee who insists on marrying is Andreia with less academic and professional qualifications. Again, reality shows that the modernizing tendencies of the couple and the family do not reach all individuals in the same way or with the same intensity.

Several investigations have shown the strong relation between groups with lower school and professional capitals and the valorization of the formal tie of the conjugal union $[17,18]$. For them, the marriage is perceived as a statutory advantage and an important source of social identity, especially for women [17].

If the low adherence to "gay marriage" by interviewees, on the one hand, does not distinguish them from other young adults, also educated, who demonstrate a strong disinterest in the institution of matrimony [17], on the other hand this aspect can be interpreted through life course perspective.

Because our interviewees are in recent conjugal unions, the uncertainty of the future allies to the work precariousness context to make it possible that they might want only to marry when they transit to parenthood. The parenting project comes with an always difficult "coming out", and perhaps marriage could be a way to minimize the sexual orientation revelation negative impact to the family networks and to help to provide the homoparental family social recognition, both in the private sphere and the public sphere.
In the transition to parenthood the couple becomes less privatized [17] and the coming of a child to a homoparental context can mean an increased concern about social recognition, rights and security of family members. Meanwhile, having a child implies a close relationship between the homoparental family and the school and health institutions.

Perhaps at this phase of their conjugal and family life, adherence to same-sex marriage is regarded as likely to make it easier the social life and therefore could have more followers among our interviewees in the moment to transition to parenting. Until then, with their conjugal experiences, the interviewees live in a kind of social uncertainty concerning their sexual orientation and gender identity. Some of them say they are either bisexual or they are judged as so by their families, which could be interpreted as a defensive strategy.

Bisexuality seems to be better socially accepted than homosexuality, since you have a foot on the "normal" heterosexual world and at the same time, the other foot on the non-heterosexual world. Therefore, family members can see it as a reversible situation in which "not everything is lost", making it possible the return to "normality."

Luis: "First, they were shocked and then when they accepted that he [Luis' partner] could be bisexual, they started saying things like" they can date but they do not have to live together."

Ema: "I'm bisexual... I thought I should never tell my parents unless I started a serious relationship with a girl. I have a more serious relationship right now, but I think the time has not yet come to tell them."

Andreia: "Maybe I'm bisexual because I'm attracted to boys and girls, but I think that in order to have longer relationships I identify more with girls because of their personality."

Telling family and friends that you are bisexual instead of declaring or self-identifying as homosexual can be interpreted as a way to create ambivalence and increase social acceptance both of the sexual orientation and of the conjugal relationship.

Ema, for instance, despite having a love affair for more than four years followed by nine months of conjugal cohabitation, justifies not telling her parents about the relationship with her bisexuality, as if she was waiting to go back to date a men and, at the same time, perspective her current homosexual relationship as a reversible and transitory situation. This is an aspect where we can see the internalized homophobia [23] $]^{7}$.

\footnotetext{
6 The movement of privatization joined with the growing sentimentalization of the couple and the family (the loving feeling is the grounds for the union and the children become "objects of affection"), means, on one hand, the decline in the exterior regulation exercised by the community, by neighbours and by the family network and, on the other hand, the progressive importance of the individual in social relations, the valorization of their choices and their personal and affective realization (Ariès, 1973; Shorter 1975 in [17] Santos, 2013). This is a central dynamic of the modernization process of Western Societies which
}

some authors understand as "individualization" (Beck and Beck-Gernsheim, 1995; Elias, 1991 in [17] Santos, 2013).

\footnotetext{
${ }^{7}$ Understood as "the one that the victims of homophobia itself (...) carry within themselves as mechanisms of containment, self-censorship, objection, fear (...)" (Almeida, 2004 in [16] Dias, 2018: 24).
} 
We know, however, that despite the apparent solidity of identity and sexual orientation, they are fluid and variable throughout the individuals' life span [11].

Nowadays, there is also a growing dissociation between sexuality and procreation and between conjugality and children, concerning love and conjugality. If it is true that Luís points out as a basic requirement for having children the conjugal stability (not necessarily under marriage) and economic stability, the women interviewed only mention the economic stability, revealing greater autonomy to exercise motherhood outside marriage, conjugality and without help from men.

Despite advocating gender equality, the interviewers are not immune to the constraints of the social order of gender. Luís reproduces, in a less stereotyped way, some of the conventional representations and dimensions of masculinity and feminity. He is worried about the relational issues in the adolescence and feels insecure to deal with the female universe, mainly concerning sexuality issues.

Luís: "(...) girls have menstruation and it takes sensitivity to talk and deal with it ... then come the experiences, alcohol, drugs, friends, dating ... I think it should be the most complicated phase for parents."

Luís is a case that confirms the greater dependence of gay men on woman to exercise parenthood and educate children [24]. Lesbians, on the other hand, feel that they do not need men much to be mothers and rise children, revealing greater autonomy towards the projects and the exercise of parenting.

Ema: "I know cases of single mothers that children are happy and possibly would be even more so if they were two mothers. In fact, often the male figure only harms, even in a heterosexual couple."

Sónia: "I consider that if a couple [of two women] educate well a son, there is no need of a man, because education has nothing to do with sex. In fact, we have many examples of dysfunctional children who come from "normal" families and other children who come from a family where the single parent has to be both mother and father at the same time and does an excellent work."

Andreia: "It's not the same [being a mother and being a father], but I think they can do the same things. There are single mothers and fathers who do everything and have spectacular children, without those typical problems of dysfunctional families."

Luís: "I think a female influence can be useful ... of course, it may be easier for a girl to talk to her mother or the boy about certain things with her father, especially in adolescence, but nothing that cannot be learnt."
The discourses of our interviewees suggest, along with other studies [24], that gay men when compared with lesbians, reproduce more the beliefs about specific competences of women (emotional, relational) associated with the maternal role of the female. Studies with heterosexual men [19], has shown the same results and advocates that the principal obstacle to change the men's place in the Portuguese families is the strong idea that women are different because they are mothers and mothers are irreplaceable.

But we also may think that our interviewees feel that they need not a man to raise their children precisely because they believe they have those parental skills that men have not. Indeed, the research on homoparental families reveals that the motherhood ideology is very present is lesbian mothers $[15 ; 23]$ which leads Gato and Fontaine to affirm that "two lesbian women who chose to become mothers seem to function as a double dose of a feminine approach to parenting" [25]. Besides, even though there is less research on gay parents than on lesbian mothers, the literature review reveals a closer approximation of male homoparentality compared to heteroparentality [5].

A gay man who assumes homoconjugality and wants to be parents is part of a group that has already get over from a series of barriers and therefore, deviates from hegemonic masculinity [26] and stereotypes about masculinity and femininity [5]. In several dimensions of his speech Luís seems to fit on this profile.

He says that dealing with daughters is nothing that cannot be learned and that, nowadays, "we are educated and prepared for everything and both mother and father can teach whatever." He further states that "two parents or two mothers can be good parents together and support each other in the education of their children".

It is important to note that in responding to questions related to children's education, Luís refers to the disciplinary dimension, traditionally linked to the role and authority of the father, which is more absent from the discourse of the woman interviewees. However, it also emphasizes the emotional and relational aspects of communication, usually associated with the female parental role.

Another important thing that emerged from the interviews analysis and that reinforces the idea that homosexual couples are not immune to the social constraints of gender is the question of access to parenting and how to achieve the desire to become a parent. The women interviewed reveal a greater reflexivity about the way of accomplishing the parenting project. Sónia already knows that she will choose adoption and Andreia intends to have a biological child (one each partner). Meanwhile, Luís leaves open the possibilities, revealing that he had not thought much about it, despite the strong desire and the dream of becoming father.

Luís: "(...) for my grandmother, it's okay for me to marry a girl and have children and I think a little bit like that, but of course without the part of marrying a girl" (laughs).

"(...) couple with children [family ideal] because I want and always wanted to have children. That's what I want for myself, but of course, there are very different families and that's not why they're not a family". 
Luís believes that when he decided to have a child it will be easier than today, both in the variety of forms of access and the legislation.

Luís: "I think that with the new laws it is easier and at the right time will still be easier... and there are many options, adoption, surrogacy."

Despite the interviewee does not see sexual orientation as an obstacle to the realization of the parental project, he says that only wants to have children after the death of his grandparents, because he does not want to disappoint them.

Luís: "... I will probably wait for the death of my grandfathers, I know it may seem horrible to say this, but I did not want to give them heartbreak, to deceive them, my grandmother is very fragile".

Luís believes the obstacles to the realization of his desire to be a father are no longer in the "outside", in the public sphere, as they are not related to legal constraints, but to relational and emotional difficulties with the persons of the your most intimate universe. The question of acceptance and recognition of homoparentality by non significant others do not concern Luis but the feelings and negative reaction of the grandfathers, whom he sees as parental figures.

Like the women interviewed, especially those with the highest educational qualifications, Luís considers the children a source of personal gratification, along with other spheres of fulfillment and the pursuit of happiness, which, on the one hand, involve the existence of a conjugal love relationship and, on the other hand, for having a job they like.

For most heterosexual people [27] and for non-heterosexuals [24] both the economic stability and affective stability of the couple are the fundamental requirement for the decision to have children. All our interviewees share this idea, namely Luis:

Luis: "I would like to have a job that was not just to pay the bills ... to have a safer work contract to have more stability, to buy a house, to have a stable relationship and to have two children, a normal life".

\section{CONCLUSION}

If non-heterosexual persons and their families are not the only protagonists of the transformations of private life, the study reveals that they play an undoubtedly role on the deinstitutionalization and individualization of family relations and gender social relations in Portugal.

Our interviewees make no moral distinction between homoparental families and heteroparental families but continue to feel that the conjugal family built around the couple is the ideal context for raising and educating children, for economic reasons, mutual support and emotional support.

Individuals who participated in this study, of both sexes, are also of the opinion that gay parents and lesbian mothers are equally competent to raise and educate children. However, in the same way as other studies demonstrated, there are some significant gender differences that are mainly related to the lower autonomy of men and the greater autonomy of women in relation to parenting projects; also, about the difficulties, that they imagine they must face in the performance of parental roles. It will not be by chance that Luis, our only male interviewee, speaks about the need of some help from a female figure who, according to him, does not necessarily have to be a mother, but which may come, for example, from grandmothers and friends. However, we would like to emphasize that all respondents tend to deviate from the more stereotyped dimensions of femininity and masculinity.

Precariousness at work generates uncertainty about the future of the Portuguese youth with negative impact, both on personal autonomy and on the decision to have children. LGBT people are not exception to those reality, but they face the cumulative disadvantage of the disclosure of sexual orientation and gender identity to family members.

Knowing the importance of the Portuguese family as a social support network, due to the exclusion of this social resource, young non-heterosexual may be even more unprotected, from the materially and affective point of view, than other young heterosexual people.

Regarding future investigations, it seems important to consider the question of bisexuality as a defensive strategy that approaches individuals to heteronormative ideal. Could it be a form of self-censorship? Or is it a way of free expression of sexual orientation and gender identity? There is a need to further the knowledge about those questions.

In addition, there is a need for a longitudinal study following the life course of non-heterosexual individuals in order to know the adherence and the impact that same-sex marriage has on the transition to parenthood, in families, in social institutions, and in the context of Portuguese society in general.

\section{REFERENCES}

[1] Costa, P.; Caldeira, S.; Fernandes, I.; Rita, C.; Pereira, H. \& Leal, I. (2013). Atitudes da População Portuguesa em Relação à Homoparentalidade. Psicologia: Reflexão e Crítica, 26 (4), pp. 790-798.

[2] Almeida, M. (2006). Homoparentalidade: Uma Perspectiva Antropológica. In: Ferreira, E. (Org.), Proceedings from Encontro sobre Homoparentalidade, 3rd July 2004, Lisboa: ISPA, pp 25-30.

[3] American Psychological Association (APA) (2005). Lesbian \& Gay Parenting. Washington: APA; Committee on Lesbian, Gay, and Bisexual Concerns (CLGBC); Committee on Children, Youth, and Families (CYF); and Committee on Women in Psychology (CWP).

[4] Costa, P.; Pereira, H; \& Leal, I. (2012). Homoparentalidade: O Estado da Investigação e a Procura de Normalização. Psicologia, XXVI (1), pp. 5569.

[5] Gato, J. \& Fontaine, A. M. (2011). Impacto da orientação sexual e do género na parentalidade: uma revisão dos estudos empíricos com famílias homoparentais. Ex æquo, 23, pp. 83-96.

[6] Patterson, J. C. (2000). Family Relationships of Lesbians and Gay Men. Journal of Marriage and The Family, 62, pp. 1052-1069. 
[7] Aboim, S. (2016). Trans-masculinities, embodiments and the materiality of gender: bridging the gap. International Journal for Masculinity Studies, 11(4) pp. 225-236.

[8] Hines, S.; Davy, Z.; Monro, S.; Motmans, J.; Santos, A. C.; Van Der Ros, J. (2017). Introduction to the themed issue: Trans* policy, practice and lived experience within a European contexto. Critical Social Policy, 38 (1) pp. 5-12.

[9] Santos, A. C. (2012). The politics of sexuality in Portugal: confronting tradition, enacting change. S. Hines and Y. Taylor (eds.). Sexualities: Reflections and Futures. Basingstoke: Palgrave-Macmillan, pp. 168-185.

[10] Almeida, M. V. (2010). O contexto LGBT em Portugal. In: C. Nogueira \& J. M. Oliveira (Orgs.). Estudo sobre a discriminação em função da orientação sexual e da identidade de género. Lisboa: Comissão para a Cidadania e a Igualdade de Género, pp 45-90.

[11] Nogueira, C. \& Oliveira, J. M. (Orgs.), (2010). Estudo sobre a discriminação em função da orientação sexual e da identidade de género. Lisboa: Comissão para a Cidadania e a Igualdade de Género.

[12] Gato, J. (2013). De que falamos quando falamos de preconceito contra a homoparentalidade: Atitudes face à competência parental e ao desenvolvimento psicossocial das crianças. In: Proceedings from Famílias no plural: alargar o conceito, largar o preconceito., Lisboa: ILGA Portugal \& CRIA, pp. 59-85.

[13] Nico, M.; \& Rodrigues, E. (2011). Organização do trabalho doméstico em casais do mesmo sexo. Sociologia: Problemas e Práticas, (65), pp. 95-118.

[14] Santos, F. (2017). Mães iguais às outras? Questionando o Género e as famílias homoparentais a partir de um estudo de caso. In: Poster presented at the XXVIII Conference of the Portuguese Society of Psychoanalysis Sexualidade Contemporânea e Psicanálise, Lisboa, ISCTE, 5th and 6th May 2017.

[15] Santos, F. \& Dias, R. (2017). Homoparenthood: Family Dynamics and Individual Biographies. In: Abstract from Queering Parenting, 2ND Intimate International Conference, 2nd and 3rd March 2017, Centre for Social Studies/CES, Coimbra, Portugal.

[16] Dias, R. (2018). Gays e Lésbicas: Percursos, Interações Conjugais e Projetos de Parentalidade. (Master final thesis). Universidade da Beira Interior, Covilhã, Portugal.
[17] Santos, F. (2013). Without ceremony and without papers. The diversity of conjugal cohabitation in Portugal. Journal of Education, Psychology and Social Sciences, 1 (1), pp. 31-44.

[18] Wall, K. (org.) (2005). Famílias em Portugal. Lisboa: Imprensa das Ciências Sociais.

[19] Wall, K., Sofia, A. \& Cunha, V. (coord.) (2010). A Vida Familiar no Masculino. Negociando velhas e novas masculinidades. Lisboa: CITE.

[20] Bertaux, D. (1997). Les Récits de Vie. Paris: Nathan Editions.

[21] Cardenal, E. (2016). Biography and Story in Sociological Analysis. The Contribution of the BNIM (Biographic-Narrative Interpretive Method) School. Revista Española de Investigaciones Sociológicas, 155, p. 58.

[22] Santos, F. (2012), O Papel da Sexualidade nos Percursos de Formação dos Casais Coabitantes: Género, Mudanças Geracionais e Contextos Sociais. In: Proceedings from the VII Portuguese Congress of Sociology, Society, Crisis and Reconfigurations, 19th to 22nd June, Porto: Portuguese Association of Sociology.

[23] Almeida, M. V. (2009). A chave do armário: Homossexualidade, casamento, família. Lisboa: Imprensa das Ciências Sociais.

[24] Aboim, S.; Costa, C. \& Gomes, N. (2012). Famílias LGBT e Políticas Públicas. Presentation prepared for the Seminário Políticas Públicas e Novas Parentalidades, Observatório das Famílias e Políticas de Família (OFAP), ICS-IUL.

[25] Gato, J. \& Fontaine, A. M. (2011). Impacto da orientação sexual e do género na parentalidade: uma revisão dos estudos empíricos com famílias homoparentais. Ex æquo, 23, p.87.

[26] Aboim, S. (2010). Plural masculinities. The remaking of the self in private life. Aldershot: Ashgate.

[27] Cunha, V., Vilar, D., Wall, K., Lavinha, J. \& Pereira, T. P. (Orgs.). (2016). A(s) Problemática(s) da Natalidade em Portugal: Uma Questão Social, Económica e Política. Lisboa: Imprensa de Ciências Sociais. 